ISSN: $1858-4837$

E-ISSN: 2598-019X

Volume 13, Nomor 2 (2018),

https://jurnal.uns.ac.id/region

\title{
Dampak Perkembangan Aglomerasi Industri Gondangrejo, Karanganyar terhadap Perubahan Spasial
}

\author{
The Impact of Agglomeration Development of The Gondangrejo, \\ Karanganyar Industry on The Spatial Changes
}

\section{Darul Amal Sholihah a*, Soedwiwahjono ${ }^{b}$, Kusumastuti ${ }^{c}$}

\author{
${ }^{a}$ Prodi Perencanaan Wilayah dan Kota, Fakultas Teknik, Universitas Sebelas Maret \\ ${ }^{b}$ Prodi Perencanaan Wilayah dan Kota, Fakultas Teknik, Universitas Sebelas Maret \\ ${ }^{c}$ Prodi Perencanaan Wilayah dan Kota, Fakultas Teknik, Universitas Sebelas Maret \\ *Corresponding author's email: darulsholihah.11a4.07@gmail.com
}

\begin{abstract}
Abstrak
Industri merupakan suatu aktivitas ekonomi yang mampu memicu konsentrasi spasial. Terkonsentrasinya industri pada suatu kawasan tidak terlepas dari pemilihan lokasi yang didasarkan pada faktor kebijakan, sarana prasarana, pasar, serta dampak yang ditimbulkan. Salah satu dampak yang menjadi pertimbangan dari terpusatnya aktivitas industri adalah peristiwa aglomerasi. Berdasarkan observasi lapangan tahun 2018, aglomerasi industri Gondangrejo berada di sepanjang jaringan Jl. Solo Purwodadi guna mendapatkan kemudahan aksesibilitas. Konsentrasi industri Gondangrejo semakin berkembang dengan adanya dukungan peruntukan ruang di dalam RTRW Kabupaten Karanganyar tahun 2013-2032. Penelitian ini membahas dampak perkembangan aglomerasi industri Gondangrejo, Karanganyar terhadap perubahan spasial. Penelitian ini menggunakan data primer berupa observasi lapangan dan wawancara serta data sekunder. Teknik analisis yang digunakan adalah metode analisis skoring, overlay, korelasi, dan deskriptif. Perkembangan aglomerasi industri Gondangrejo dapat diidentifikasi melalui perkembangan jumlah industri, kedekatan lokasi industri yang mengelompok, dan peningkatan jumlah tenaga kerja industri. Hal ini berdampak terhadap perubahan spasial yang dapat diidentifikasi melalui perkembangan sarana prasarana seperti penambahan jaringan jalan, penurunan tingkat pelayanan jalan, perubahan sarana transportasi umum, perubahan guna lahan, peningkatan sarana permukiman, dan peningkatan bangunan permukiman. Perkembangan aglomerasi industri Gondangrejo berdampak bagi perubahan spasial yaitu memunculkan pusatpusat pertumbuhan baru di sekitar kawasan industri, sehingga terdapat perbedaan yang jelas antara zona kawasan pertumbuhan dengan zona kawasan permukiman pedesaan.
\end{abstract}

Kata Kunci: Aglomerasi; Dampak; Industri; Konsentrasi; Spasial;

\begin{abstract}
Industry is an economic activity that is able to trigger spatial concentration. The concentration of industry in a region can not be separated from the selection of locations based on policy factors, infrastructure, markets, and impact. One of the impact of the consideration from centralization of industrial activity is the agglomeration event. Based on field observation in 2018, Gondangrejo industrial agglomeration is located along the $\mathrm{Jl}$ solo purwodadi network get easy accessibilitasi. Gondangrejo industrial concentration is growing with the support of space designation in RTRW Karanganyar district in 20132032. This research discusses the impact of agglomeration development of Gondangrejo industry, Karanganyar to spatial changes. This research uses primary data in the form of field observation and interview and secondary data. Analytical technigue used overlay, correlation, and descriptive. The development of Gondangrejo industrial agglomeration can be identified through the development of the number of insudtrial, the proximity of the clustered industrial sites and the increasing number of industrial workes. This has an impact on spatial changes that can be identified through the development of
\end{abstract}


Region, Vol. 13, No.2, Juli 2018: 115-132

infrastructure facilities such as the addition of road network, decreased levels of road service, changes in public transport land use change, upgrading of residential buildings. Gondangrejo industrial agglomeration developments have an impact on the spatial changes, that bring up new centers of growth around the industrial estate, so there is a clear distinction between the growt zone and the zona of the village settlement area.

Keywords: Agglomeration; Concentration; Impact; Industry; Spatial

\section{PENDAHULUAN}

Berdasarkan Pedoman Teknis Kawasan Industri Tahun 2010, berkembangnya suatu kawasan industri tidak terlepas dari kriteria pemilihan lokasi yang mempertimbangkan jarak ke pusat kota guna memberikan kemudahan fasilitas pelayanan sarana prasarana dan pemasaran, serta mempertimbangkan dampak yang akan ditimbulkan akibat pengembangan kawasan. Fujita, 2005 dalam Tilaar, 2010 menyatakan bahwa keberadaan industri pada lokasi tertentu akan berakibat pada konsentrasi spasial (aglomerasi). Menurut Montgomery dalam Kuncoro (2002), aglomerasi merupakan konsentrasi spasial dari kegiatan ekonomi di suatu kawasan dengan alasan penghematan (economies of proximity).

Aktivitas industri yang terdiri dari proses produksi dan distribusi akan mempengaruhi keruangan (spasial) wilayah (Ginting, 2007). Hal ini juga didukung dengan pendapat Prihanto dalam penelitiannya bahwa perkembangan di bidang industri berakibat terhadap aspek fisik spasial yaitu alih fungsi lahan permukiman dan sarana prasarananya. Industri-industri yang teraglomerasi akan memicu daya tarik bagi pertumbuhan wilayah, seperti migrasi tenaga kerja yang mempengaruhi penggunaan lahan dan memicu perkembangan permukiman, sistem pergerakan industri yang memicu perubahan jaringan jalan dan transportasi wilayah, serta aktivitas industri yang mempengaruhi kualitas lingkungan (Prihanto, 2010).

Kota Surakarta merupakan salah satu kota di Provinsi Jawa Tengah yang berpengaruh terhadap pertumbuhan industri-industri di sekitarnya. Keberadaan Kota Surakarta menawarkan kemudahan dalam pemasaran industri, kemudahan investasi baru, teknologi baru, serta tenaga kerja terdidik dan terampil. Berdasarkan Kabupaten Karanganyar dalam Angka 2016, sejak tahun 2011 hingga 2015 PDRB dari sektor industri selalu mengalami peningkatan setiap tahunnya. Salah satu kawasan industri yang sangat berpengaruh terhadap perkembangan industri di Kabupaten Karanganyar adalah kawasan industri Gondangrejo. Berdasarkan data dari Kecamatan Gondangrejo tahun 2016, terdapat 40 industri sedang dan besar yang tersebar di kawasan Gondangrejo. 
Darul Amal Sholihah dkk, Dampak Perkembangan Aglomerasi Industri... Survey primer (2018) menunjukkan perkembangan industri Gondangrejo terkonsentrasi di sepanjang koridor Jalan Solo Purwodadi. Hal ini semakin didukung dengan kebijakan peruntukan lokasi industri di bagian barat, mengingat wilayah di bagian timur merupakan kawasan cagar budaya Situs Sangiran. Keberadaan jaringan jalan ini menjadi aksesibilitas utama bagi pergerakan transportasi industri di Gondangrejo. Seperti fakta dasar perkembangan keruangan (spasial) menurut Ferroux, 1955 dalam Tilaar, 2010, bahwa pertumbuhan tidak terjadi di sembarang tempat dan juga tidak terjadi secara serentak namun pertumbuhan itu terjadi pada titik-titik atau kutub-kutub perkembangan dengan intensitas yang berubah-ubah dan pertumbuhan itu menyebar sepanjang saluran-saluran yang beraneka ragam terhadap keseluruhan perekonomian.

Berdasarkan hasil pencarian data primer (2018) keberadaan perusahaanperusahaan industri Gondangrejo yang berada di sekitar lahan pertanian/tegalan dan lahan permukiman, menimbulkan dampak terhadap penurunan luas lahan pertanian/tegalan dan peningkatan luas lahan permukiman. Data yang didapatkan dari Kecamatan Gondangrejo dalam angka tahun 2016, penurunan luas lahan pertanian/tegalan selama tahun 2015-2016 sekitar 4,5\%. Penurunan luas lahan pertanian ini dipicu oleh kebutuhan akan perluasan lahan industri. Sementara kebutuhan industri terhadap tenaga kerja berakibat pada peningkatan luas lahan permukiman dan perumahan terlihat dari munculnya hunian seperti Green Firdaus Resident, Perum Wonorejo, dan Grand Permata. Peningkatan hunian tidak hanya terjadi di kawasan budidaya sekitar industri, melainkan juga di kawasan lindung sekitar yang memiliki aksesibilitas menuju lokasi industri. Maka dari itu pada penelitian ini, penulis ingin mengetahui bagaimana dampak perkembangan aglomerasi industri Gondangrejo, Karanganyar terhadap perubahan spasial.

\section{KAJIAN LITERATUR}

\subsection{Pengertian Dampak}

Menurut Kamus Besar Bahasa Indonesia, dampak adalah besaran, pengaruh yang mendatangkan akibat, baik positif maupun negatif. Pengaruh adalah suatu keadaan dimana ada hubungan timbal balik atau sebab akibat antara apa yang mempengaruhi dan apa yang dipengaruhi (KBBI Online, 2018). Dengan mengetahui hubungan dan besaran hubungan maka akan diketahui bagaimana dampak yang ditimbulkan antara variabel terdampak dan variabel yang memberi 
Region, Vol. 13, No.2, Juli 2018: 115-132

dampak. Dalam hal ini adalah dampak dari perkembangan aglomerasi industri terhadap perubahan spasial, yang dapat berupa dampak positif maupun dampak negatif.

\subsection{Industri dan Kawasan Industri}

Menurut Undang-Undang Nomor 3 Tahun 2014 tentang Perindustrian, industri adalah seluruh bentuk kegiatan ekonomi yang berupa kegiatan mengolah bahan baku dan memanfaatkan sumber daya sehingga menghasilkan barang yang bermanfaat dan memiliki nilai jual tinggi. Industri dikelompokkan menjadi 3 jenis, yaitu: industri kecil, industri menengah, dan industri besar.

Kawasan industri adalah kawasan yang menjadi tempat pemusatan kegiatan industri yang dilengkapi dengan sarana prasarana penunjang yang dikembangkan dan dikelola oleh perusahaan kawasan industri. Kawasan industri merupakan luasan lahan yang ditetapkan atau diperuntukkan dan telah dikembangkan sebagai area perindustrian bagi perusahaan-perusahaan industri (Undang-Undang Nomor 3 Tahun 2014). industri menurut Djojodipuro, 1992 dalam Tilaar, 2010 adalah faktor (1) pasar, (2) biaya angkutan, (3) kebijakan pemerintah, dan (4) aglomerasi.

\subsection{Teori Perkembangan Aglomerasi Industri}

Menurut Markusen dalam Kuncoro (2020), aglomerasi merupakan suatu peristiwa penghematan dari perusahaan-perusahaan yang letaknya saling berdekatan. Sementara itu, menurut Lipcznski, et. al., 2005 dalam Arsyad, 2014, mengemukakan bahwa peristiwa aglomerasi tidak selalu terjadi pada jenis industri yang sama atau berkaitan, melainkan dapat terjadi dari industri memiliki perbedaan dari segi produk atau dari segi wilayah operasi (pemasaran).

Krugman dalam Kuncoro (2002:1), menyebutkan bahwa aglomerasi di kota-kota di Indonesia terjadi karena akumulasi modal dan tenaga kerja. Akumulasi modal dan tenaga yang dimaksudkan oleh Krugman adalah bahwa terpusatnya perekonomian kota di suatu kawasan dan terpusatnya sumberdaya manusia sebagai tenaga kerja memicu industri dalam menanamkan modalnya. Teori Krugman kemudian dilengkapi oleh Martin dan Sunley bahwa, aglomerasi industri juga mempertimbangkan lokasi pasar guna meminimasi biaya transaksi dan meningkatkan kekuatan perusahaan sebagai produsen besar (Marten dan Sunley, 1996 dalam Kuncoro, 2002).

Sementara itu, teori-teori lokasi yang tradisional berpendapat bahwa pengelompokan industri diakibatkan karena minimisasi biaya transpor atau biaya produksi (Isard, 1956; Weber, 1909 dalam Kuncoro 2002:2). Minimisasi biaya 
Darul Amal Sholihah dkk, Dampak Perkembangan Aglomerasi Industri... transpor dan biaya produksi diartikan sebagai mengeluarkan modal seminimal mungkin dengan maksud dapat memaksimalkan penjualan melalui area pasar yang terluas. Selain itu, Weber, 1909 dalam Tarigan, 2012, juga mengungkapkan bahwa lokasi industri juga didasarkan pada faktor tenaga kerja dan dampak aglomerasi. Industri akan cenderung berlokasi pada daerah yang dekat dengan sumber tenaga kerja. Sehingga diharapkan dapat melahirkan biaya terendah dan memaksimalkan keuntungan perusahaan. Weber juga mencoba menggabungkan keuntungan biaya transportasi dengan tenaga kerja melalui dampak aglomerasi. Aglomerasi memberikan keuntungan lain berupa ketersediaan sarana prasarana penunjang kegiatan industri. Keuntungan tersebut seperti ketersediaan jaringan air bersih, jaringan listrik, fasilitas kesehatan, fasilitas pendidikan, dan lain-lain. Untuk menentukan apakah industri teraglomerasi atau tidak, dapat digunakan analisis tetangga terdekat yaitu dengan rumus parameter tetangga terdekat yang dirumuskan oleh Bintarto dan Hadisumarno. Rumus parameter tetangga terdekat menurut Bintarto dan Hadisumarno, 1989 dalam Tambunan, 2002 adalah sebagai berikut:

$$
\mathrm{T}=\frac{j u}{j h}
$$

Keterangan:

$\mathrm{T}$ : Indeks kumulatif persebaran tetangga terdekat

$\mathrm{Ju}$ : Jarak rata-rata yang diukur antara satu titik dengan titik tetangga terdekat

Jh : Jarak rata-rata yang diperoleh andaikan semua titik random (Jh . $1 / 2 \sqrt{ } \mathrm{P}$

$\mathrm{P}$ : Kepadatan titik tiap $\mathrm{km}^{2}$ yaitu jumlah titik $(\mathrm{N})$ dibagi luas wilayah

Setelah diketahui angka indeks tetangga terdekat, maka angka indeks tersebut dimasukkan ke dalam klasifikasi pola persebaran. Pola persebaran tersebut yaitu:

- $\mathrm{T}=0-0,7$ berarti industri mengelompok/ bergerombol

- $\mathrm{T}=0,7-1,4$ berarti industri menyebar acak/ tidak merata

- $\mathrm{T}=1,4-2,1491$ berarti industri membentuk pola persebaran seragam

\subsection{Teori Perubahan Spasial}

Secara harfiah kata spasial berasal dari kata Spatial yang diartikan sebagai tata ruang. Menurut pendapat Suchaini (2013), spasial diartikan wilayah atau ruang. Sedangkan secara terminologis, Mulyati dalam Prihanto (2010) menjelaskan bahwa spasial adalah ruang fisik yang terbentuk pada lingkungan permukiman, rumah tinggal, dan bentuk bangunan yang terjadi karena faktor yang berkembang di lingkungan masyarakat. 
Region, Vol. 13, No.2, Juli 2018: 115-132

Bentuk fisik suatu kawasan tertentu dalam konteks suatu kota atau desa dapat disebut sebagai kajian morfologi kota/desa yang diamati dari kenampakannya. Menurut Herbert, 1973 dalam Sabari, 2002, lingkup kajian morfologi kota terdiri dari 3 unsur yang meliputi (1) sistem jalan, (2) blok-blok bangunan, dan (3) bangunan-bangunan individual. Smailes, 1955 dalam Sabari, 2002, menekankan lingkup kajian morfologi meliputi (1) penggunaan lahan, (2) pola-pola jalan, dan (3) pola bangunan. Sedangkan Johnson, 1981 dalam Sabari, 2002, memfokuskan aspek kajian morfologi kota pada (1) rencana jalan, (2) tata bangunan, serta (3) kaitan fungsional jalan dan bangunan. Berdasarkan lingkup kajian morfologi kota dari para pakar, maka dapat disimpulkan bahwa kajian morfologi kota kaitannya dalam aspek spasial meliputi sistem jaringan jalan yang terdiri dari sistem, pola, dan rencana jalan; penggunaan lahan; serta bangunan dan tata bangunan.

\subsection{Hubungan Perkembangan Aglomerasi Industri dan Perubahan Spasial}

Peningkatan kegiatan yang pesat telah menimbulkan pengaruh bagi berbagai aspek kehidupan baik spasial maupun aspasial (Ginting, 2007). Menurut Gardner dalam Abdullah (2010), disebutkan bahwa aktivitas yang berhubungan dengan kegiatan manusia akan mempengaruhi struktur ruang di dalam suatu wilayah. Adapun perubahan struktur ruang di dalam suatu wilayah selalu bertumpu pada:

- Penyesuaian faktor jarak, baik berupa rangkaian yang bersifat linier maupun non-linier. Dalam hal ini adalah jarak industri akan berdampak pada sistem rangkaian jalan di sekitar kawasan industri.

- Keputusan lokasional dari kegiatan manusia, pada umumnya, akan mendasarkan pada kriteria meminimalisasikan efek jarak.

- Pada setiap wilayah, dapat dicerminkan bahwa tingkat kemudahan di dalam pencapaian sesuatu lokasi, akan berbeda sifatnya. Keragaman kemudahan dalam pencapaian suatu lokasi akan berpengaruh terhadap masalah biaya

- Organisasi atau sistem kelembagaan di dalam kegiatan manusia mempunyai watak hierarki yang diakibatkan saling terkait antara aglomerasi dan kemudahan hubungan. Kebijakan lokasi peruntukkan industri akan didukung dengan kualitas dan kuantitas jaringan jalan yang memadai bagi perusahaan industri.

Menurut Colby, 1999 dalam Sabari, 2005, dijelaskan bahwa pola penggunaan lahan dipengaruhi oleh kekuatan-kekuatan keruangan seperti aksesibilitas, faktor pelayanan umum, karakteristik lahan, karakteristik pemilik lahan, keberadaan peraturan, dan prakarsa pengembang. Selain itu, Hagget, 1972 dalam Sabari, 2002, menjelaskan guna lahan dipengaruhi dari seluruh aktivitas makhluk hidup. 
Darul Amal Sholihah dkk, Dampak Perkembangan Aglomerasi Industri... Aktivitas industri juga berdampak terhadap penggunaan lahan, baik dari segi kuantitas maupun kualitas lahan (Hagget, 1972; dalam Sabari 2002). Sehingga dapat disimpulkan bahwa perkembagan aglomerasi industri berdampak terhadap perubahan spasial kaitannya dengan penggunaan lahan, aksesibilitas, dan pelayanan umum.

\section{METODE PENELITIAN}

Kawasan penelitian merupakan kawasan aglomerasi industri Gondangrejo dan kawasan terdampak aglomerasi industri yang memiliki luas mencapai 2900,81 ha. Kawasan terdampak aglomerasi ditentukan dengan mempertimbangkan Peraturan Menteri Perindustrian Nomor 35 Tahun 2010 tentang Pedoman Kawasan Industri dan Jurnal tentang Klasifikasi Karateristik Dampak Industri pada Kawasan Permukiman Terdampak Industri di Cemani Kabupaten Sukoharjo, sehingga kawasan terdampak aglomerasi industri ditentukan dengan menarik jarak $0-2 \mathrm{~km}$ dari tiap industri terluar, kemudian dibatasi dengan batas fisik seperti jalan, sungai, atau patok sawah.

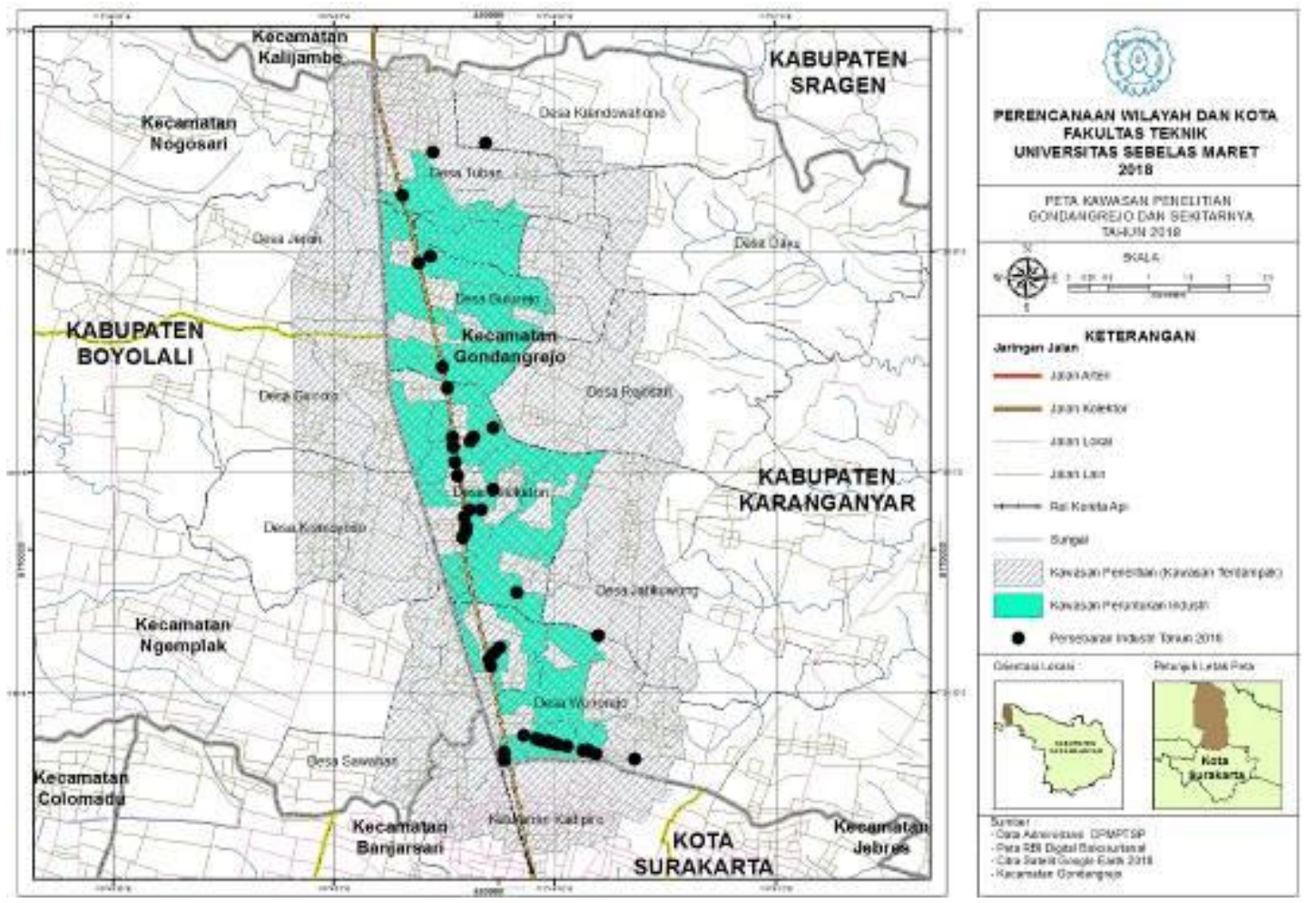

Gambar 1. Peta Kawasan Penelitian Gondangrejo dan Sekitarnya Tahun 2018 Sumber: Analisis Penulis, 2018

Penelitian mengenai dampak perkembangan aglomerasi industri Gondangrejo, Karanganyar terhadap perubahan spasial ini bersifat deduktif, yaitu bermula dari pengertian umum mengenai suatu fenomena kemudian dapat ditarik ke dalam suatu kesimpulan yang khusus. Diketahui sebelumnya, bahwa pemusatan industri 
Region, Vol. 13, No.2, Juli 2018: 115-132

memberikan pengaruh terhadap fisik spasial seperti menumbuhkan kawasan dengan beragam sarana prasarana pendukung yang berimbas pada perubahan penggunaan lahan (Prihanto, 2010). Hal ini menjadi titik tolak teori dalam penelitian dampak perkembangan aglomerasi industri terhadap perubahan spasial. Penelitian terkait aglomerasi industri dan kondisi spasial nanti pada akhirnya dapat ditarik kesimpulan dari hal yang umum ke suatu hal yang bersifat khusus. Adapun variabel yang digunakan pada penelitian ini adalah sebagai berikut:

Tabel 1. Variabel Penelitian

\begin{tabular}{|c|c|c|c|}
\hline Variabel & Sub Variabel & Indikator & Tolok Ukur \\
\hline \multirow{10}{*}{$\begin{array}{l}\text { Perkembangan } \\
\text { Aglomerasi } \\
\text { Industri }\end{array}$} & \multirow{3}{*}{$\begin{array}{l}\text { Perkembangan } \\
\text { Kedekatan } \\
\text { Lokasi Industri }\end{array}$} & \multirow{3}{*}{$\begin{array}{l}\text { Perkembangan jarak } \\
\text { minimal antar industri } \\
\text { mengelompok (indeks } \\
\text { tetangga terdekat) }\end{array}$} & Tidak berkembang \\
\hline & & & Berkembang $(\mathrm{T}>0,7)$ \\
\hline & & & Berkembang $(\mathrm{T}<0,7)$ \\
\hline & \multirow{3}{*}{$\begin{array}{l}\text { Pertumbuhan } \\
\text { Jumlah industri }\end{array}$} & \multirow{3}{*}{$\begin{array}{l}\text { Perkembangan jumlah } \\
\text { dan persebaran } \\
\text { industri }\end{array}$} & Tidak berkembang \\
\hline & & & Berkembang $(<50 \%)$ \\
\hline & & & $\begin{array}{l}\text { Berkembang }(>50 \%) \text { sesuai } \\
\text { peruntukan }\end{array}$ \\
\hline & \multirow{4}{*}{$\begin{array}{l}\text { Perkembangan } \\
\text { Jumlah tenaga } \\
\text { kerja }\end{array}$} & \multirow{4}{*}{$\begin{array}{l}\text { Perkembangan jumlah } \\
\text { dan persebaran tenaga } \\
\text { kerja }\end{array}$} & Tidak berkembang \\
\hline & & & Berkembang $(<50 \%)$ dalam \\
\hline & & & lingkup kawasan penelitian \\
\hline & & & $\begin{array}{l}\text { Berkembang ( }>50 \% \text { ) dalam dan } \\
\text { luar kawasan penelitian }\end{array}$ \\
\hline \multirow{18}{*}{$\begin{array}{l}\text { Perubahan } \\
\text { Spasial }\end{array}$} & \multirow{3}{*}{$\begin{array}{l}\text { Perubahan } \\
\text { jaringan jalan }\end{array}$} & \multirow{3}{*}{$\begin{array}{l}\text { Perubahan panjang } \\
\text { dan kondisi jaringan } \\
\text { jalan }\end{array}$} & Tidak bertambah \\
\hline & & & Mengalami penambahan \\
\hline & & & $\begin{array}{l}\text { Mengalami penambahan dan } \\
\text { sesuai standar }\end{array}$ \\
\hline & \multirow{3}{*}{$\begin{array}{l}\text { Perubahan } \\
\text { pelayanan } \\
\text { jalan }\end{array}$} & \multirow{3}{*}{$\begin{array}{l}\text { Perubahan tingkat } \\
\text { pelayanan jalan }\end{array}$} & Tidak berubah \\
\hline & & & $\begin{array}{l}\text { Berubah (tingkat pelayanan } \\
<0,75)\end{array}$ \\
\hline & & & $\begin{array}{l}\text { Berubah (tingkat pelayanan } \\
>0,75 \text { ) }\end{array}$ \\
\hline & \multirow{3}{*}{$\begin{array}{l}\text { Perubahan } \\
\text { pelayanan } \\
\text { sarana } \\
\text { transportasi } \\
\text { umum }\end{array}$} & \multirow{3}{*}{$\begin{array}{l}\text { Perubahan tingkat } \\
\text { pelayanan sarana } \\
\text { transportasi umum } \\
\text { dilihat dari jumlah dan } \\
\text { kondisi }\end{array}$} & $\begin{array}{l}\text { Rute tidak bertambah dan tidak } \\
\text { terlayani sarana transportasi } \\
\text { umum }\end{array}$ \\
\hline & & & $\begin{array}{l}\text { Rute bertambah tetapi belum } \\
\text { terlayani sarana transportasi } \\
\text { umum }\end{array}$ \\
\hline & & & $\begin{array}{l}\text { Rute bertambah, terlayani } \\
\text { sarana transportasi umum, } \\
\text { perbaikan kualitas }\end{array}$ \\
\hline & \multirow{3}{*}{$\begin{array}{l}\text { Perubahan } \\
\text { penggunaan } \\
\text { lahan }\end{array}$} & \multirow{3}{*}{$\begin{array}{l}\text { Perubahan tipe } \\
\text { penggunaan lahan }\end{array}$} & Tidak mengalami perubahan \\
\hline & & & Mengalami perubahan $<20 \%$ \\
\hline & & & Mengalami perubahan $>20 \%$ \\
\hline & \multirow{3}{*}{$\begin{array}{l}\text { Perubahan } \\
\text { pelayanan } \\
\text { sarana } \\
\text { permukiman }\end{array}$} & \multirow{3}{*}{$\begin{array}{l}\text { Perubahan jumlah dan } \\
\text { rasio pelayanan sarana } \\
\text { pendidikan, kesehatan, } \\
\text { peribadatan, dan } \\
\text { perdagangan jasa }\end{array}$} & Tidak mengalami peningkatan \\
\hline & & & $\begin{array}{l}\text { Peningkatan jumlah dan rasio } \\
\text { pelayanan }\end{array}$ \\
\hline & & & $\begin{array}{l}\text { Peningkatan jumlah, rasio } \\
\text { pelayanan, dan sesuai standar } \\
\text { minimum }\end{array}$ \\
\hline & \multirow{3}{*}{$\begin{array}{l}\text { Perubahan } \\
\text { bangunan } \\
\text { permukiman }\end{array}$} & \multirow{3}{*}{$\begin{array}{l}\text { Perubahan jumlah dan } \\
\text { persebaran jenis } \\
\text { permukiman pekerja } \\
\text { dan penduduk }\end{array}$} & Tidak mengalami peningkatan \\
\hline & & & Peningkatan jumlah bangunan \\
\hline & & & $\begin{array}{l}\text { Peningkatan jumlah bangunan } \\
\text { diiringi perubahan tata } \\
\text { bangunan }\end{array}$ \\
\hline
\end{tabular}


Darul Amal Sholihah dkk, Dampak Perkembangan Aglomerasi Industri...

Sumber: Peneliti, 2018

Variabel di atas diukur dengan menggunakan teknik pengumpulan data primer (observasi lapangan dan wawancara) dan sekunder. Sementara itu, teknik analisis yang digunakan adalah teknik analisis skoring, overlay, korelasi, dan deskripsi. Teknik analisis korelasi digunakan untuk mengetahui hubungan antara kedua variabel, sehingga dapat dilakukan skoring untuk mengetahui kekuatan dampak. Teknik korelasi mempertimbangkan matriks hubungan antar kedua variabel, sebagai berikut:

Tabel 2. Matriks Hubungan Antar Sub-Variabel Penelitian

\begin{tabular}{|c|c|c|c|}
\hline$\underbrace{}_{\text {Perkembangan }} \begin{array}{r}\text { Perubahan } \\
\text { Spasial } \\
\text { Kawasan Industri }\end{array}$ & Tidak Berubah & Berubah & Sangat Berubah \\
\hline Fidak Berkembang & Berhubungan & Tidak Berhubungan & Tidak Berhubungan \\
\hline Berkembang & Tidak Berhubungan & Hubungan Kuat & Hubungan Kuat \\
\hline Sangat Berkembang & Tidak Berhubungan & Berhubungan & Hubungan Kuat \\
\hline
\end{tabular}

Tidak berhubungan akan mendapatkan skor 0, berhubungan akan mendapatkan skor 1, dan berhubungan kuat akan mendapatkan skor 2. Akumulasi dari skor masing-masing sub-variabel akan menunjukkan besaran dampak perkembangan aglomerasi industri terhadap perubahan spasial. Dampak perkembangan aglomerasi industri Gondangrejo terhadap perubahan spasial akan diketahui melalui seberapa kuat hubungan perkembangan aglomerasi industri Gondangrejo dan perubahan spasial sehingga menimbulkan impact antara satu dengan yang lain. Setelah mengetahui besaran dampak maka akan dilanjutkan dengan teknik analisis deskriptif interpretatif.

Tabel 3. Skoring Matriks Hubungan dan Dampak yang Ditimbulkan

\begin{tabular}{|cc|}
\hline Total Skor & Dampak \\
\hline$>20$ & Sangat Berdampak \\
\hline $10-20$ & Berdampak \\
\hline $1-10$ & Cukup Berdampak \\
\hline$<1$ & Tidak Berdampak \\
\hline
\end{tabular}

Sumber: Peneliti, 2018

\section{HASIL DAN PEMBAHASAN}

Kawasan industri Gondangrejo mulai muncul sejak tahun 1990-an dan mulai berkembang pesat tahun 2000-an, dengan jumlah industri sedang dan besar mencapai 18 industri pada tahun 2003 dan 42 industri pada tahun 2018. Berdasarkan perhitungan indeks tetangga terdekat, perkembangan kawasan industri Gondangrejo sejak tahun 2003 hingga tahun 2018 selalu mengelompok, sehingga dapat diklasifikasikan ke dalam peristiwa aglomerasi industri. Berikut ini peta persebaran industri Gondangrejo dari tahun 2003 hingga tahun 2018: 

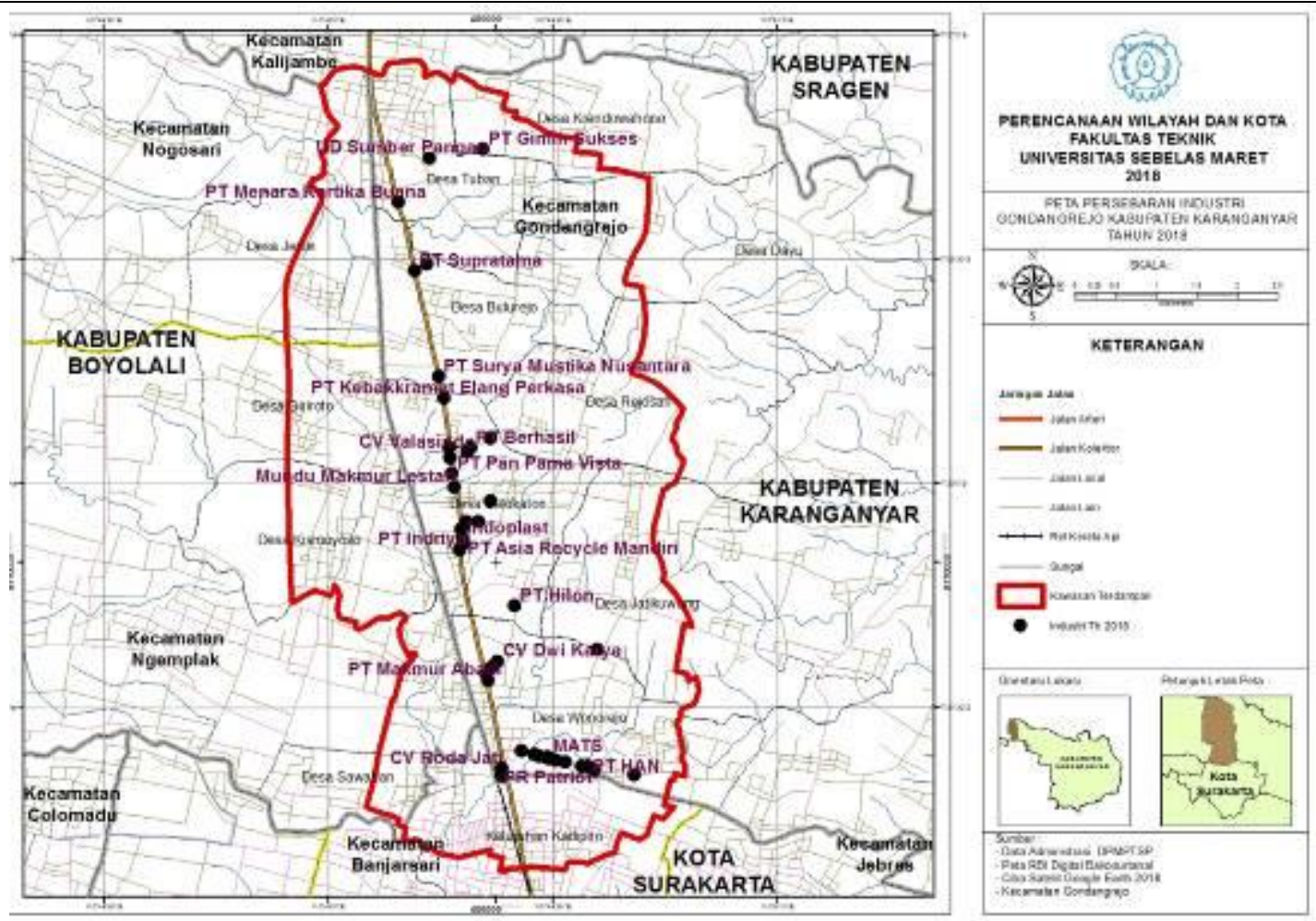

Gambar 2. Peta Persebaran Industri Gondangrejo Tahun 2003-2018 Sumber: Analisis Penulis, 2018

Perkembangan aglomerasi industri Gondangrejo ditandai dengan perkembangan industri dan perkembangan jumlah tenaga kerja. Perkembangan industri dilihat dari pertumbuhan jumlah industri dari tahun 2003 hingga tahun 2018 yang meningkat signifikan yaitu sebesar 24 industri atau mencapai 133,33\%, sebanding dengan peningkatan jumlah tenaga kerja sebesar 8.246 jiwa atau mencapai 133,40\%. Perkembangan aglomerasi industri ini didukung dengan kebijakan lokasi peruntukan industri yang diperuntukkan berkembang di wilayah Gondangrejo bagian barat, keberadaan prasarana jaringan Jalan Solo Purwodadi dan Jalan Tol Solo-Kertosono, jaringan listrik yang memadai, akumulasi tenaga kerja yang berasal dari wilayah Gondangrejo dan sekitarnya, lokasi pemasaran yang berlingkup di wilayah Soloraya, serta jenis industri yang didominasi industri berbahan plastik (35\%) dan garmen (15\%).

Perkembangan aglomerasi industri ini memicu perubahan kondisi spasial kawasan sekitar. Beberapa akibat yang ditimbulkan dari perkembangan aglomerasi industri ini adalah penambahan jaringan jalan untuk mendukung kemudahan aksesibilitas industri dan tenaga kerja, penurunan pelayanan jalan menjadi lebih jenuh karena tingginya sirkulasi dan mobilitas industri juga tenaga kerja, peningkatan sarana transportasi umum guna mendukung mobilitas tenaga kerja, alih fungsi lahan tak terbangun menjadi lahan industri, lahan permukiman, dan lahan perdagangan, peningkatan sarana permukiman guna mendukung penyelenggaraan bermukim 
Darul Amal Sholihah dkk, Dampak Perkembangan Aglomerasi Industri... masyarakat dan tenaga kerja, serta peningkatan bangunan permukiman bagi tenaga kerja industri. Berikut ini adalah perubahan spasial kawasan Gondangrejo dan sekitarnya yang tertuang dalam peta perubahan guna lahan lahan tahun 2003, tahun 2010, dan tahun 2018.

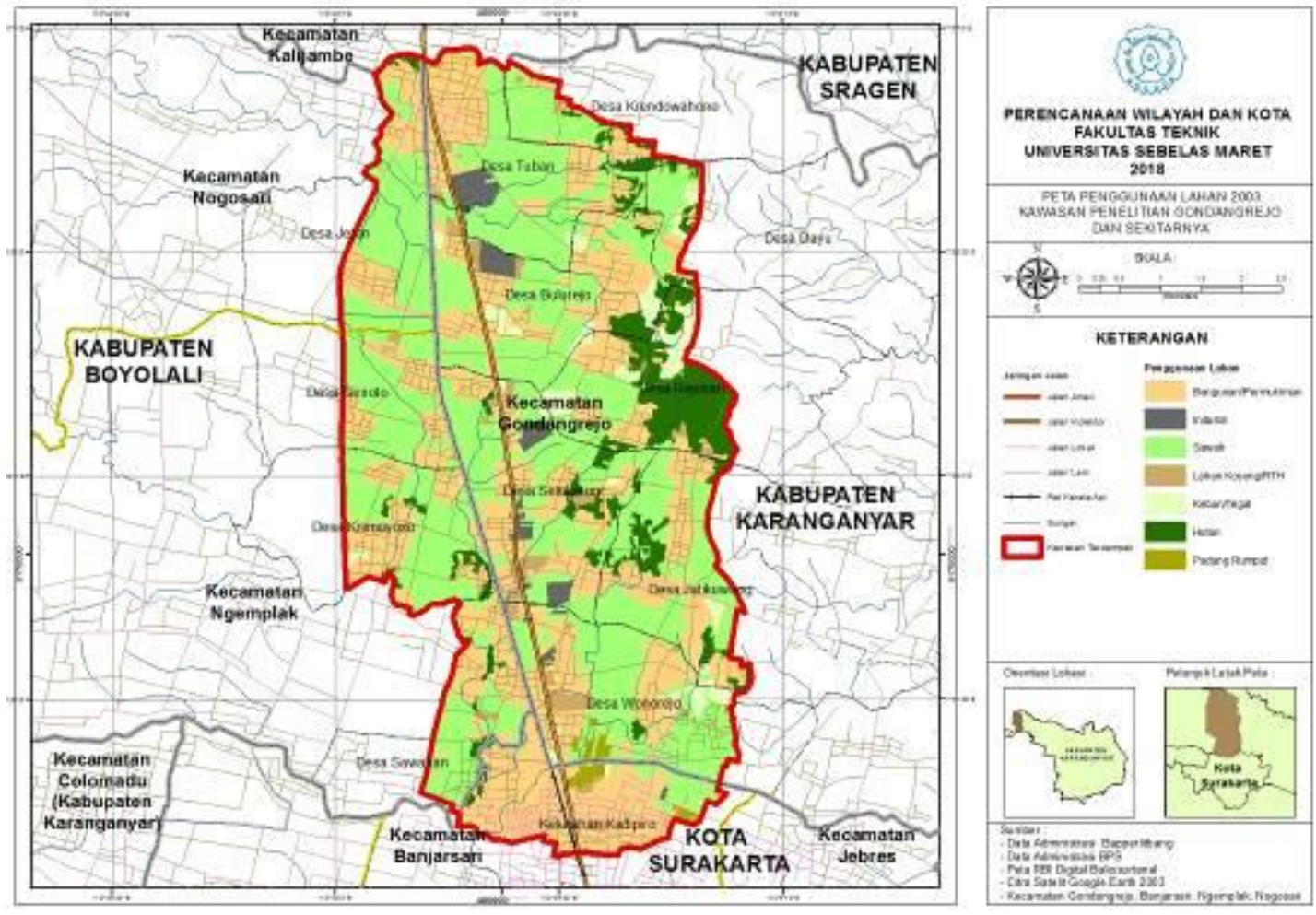

Gambar 3. Peta Penggunaan Lahan Kawasan Penelitian Tahun 2003 Sumber: Analisis Penulis, 2018

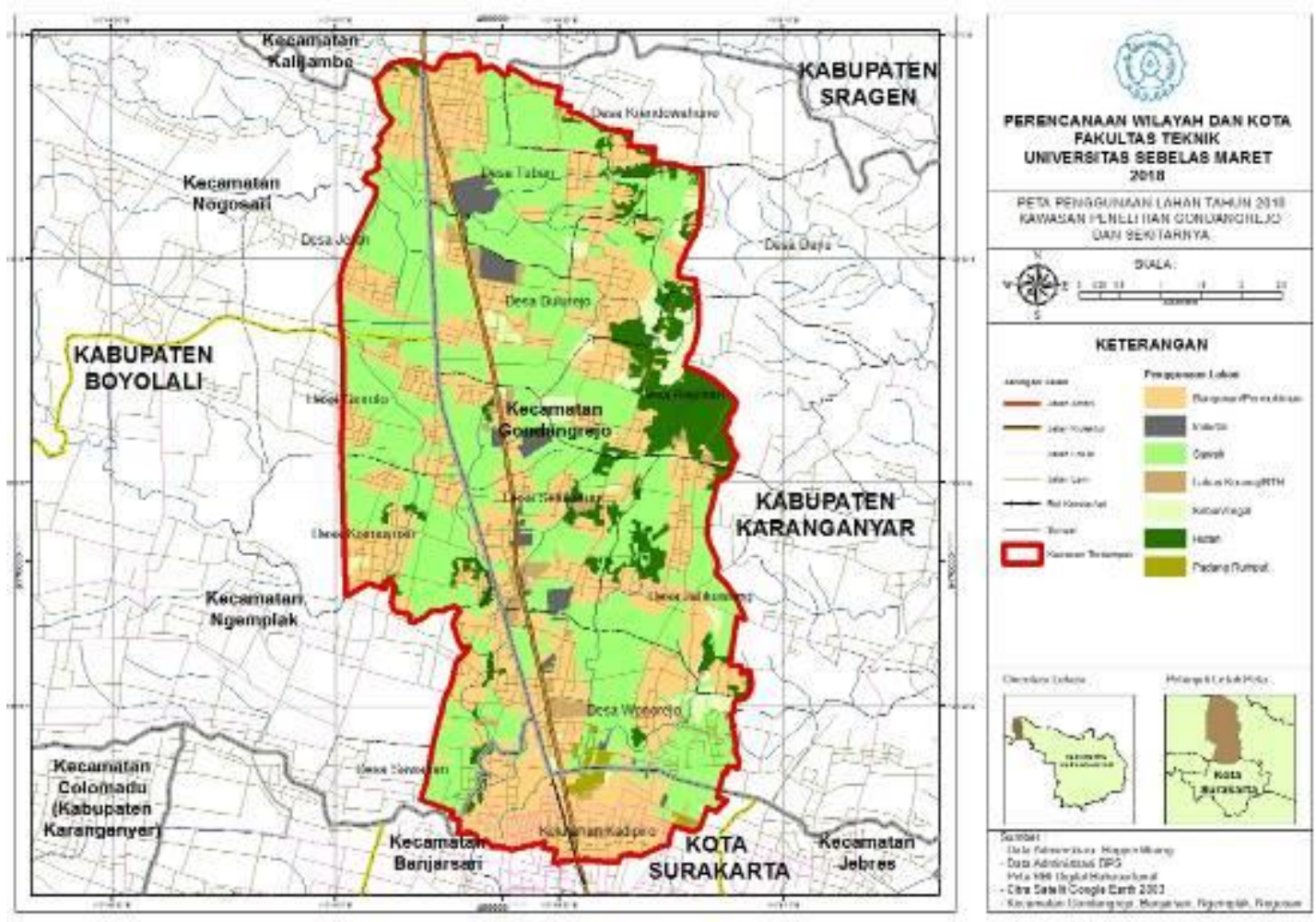

Gambar 4. Peta Penggunaan Lahan Kawasan Penelitian Tahun 2010 
Sumber: Analisis Penulis, 2018

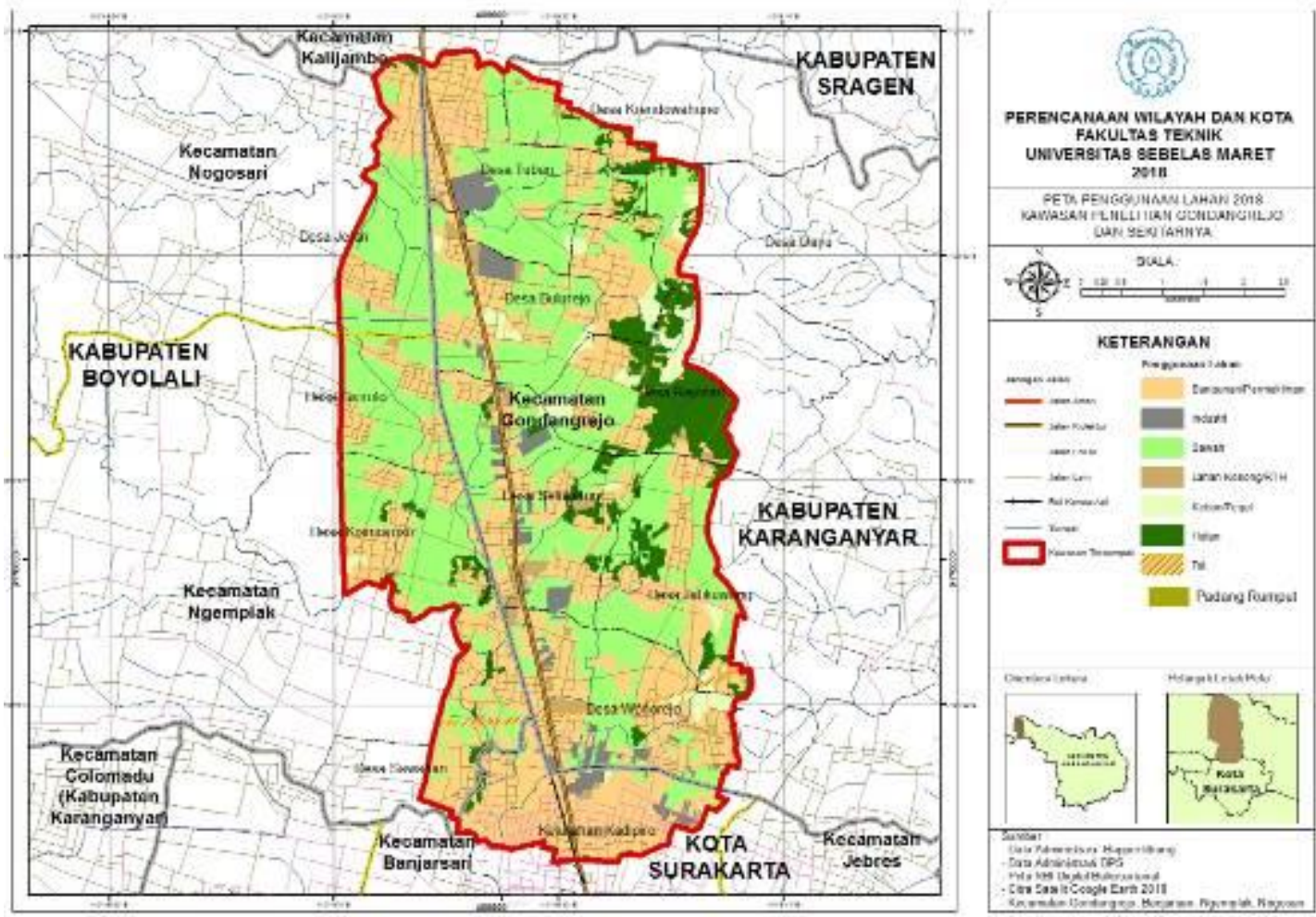

Gambar 5. Peta Penggunaan Lahan Kawasan Penelitian Tahun 2018

Sumber: Analisis Penulis, 2018

Berdasarkan data-data perkembangan aglomerasi industri Gondangrejo dan perubahan spasial yang telah didapatkan, dapat dirumuskan sintesa perkembangan aglomerasi industri Gondangrejo dan perubahan spasial sebagai berikut:

Tabel 4. Hasil Perkembangan Aglomerasi Industri dan Perubahan Spasial Tahun 2003-2018 di Kawasan Penelitian

\begin{tabular}{|c|c|c|c|c|c|}
\hline Kondisi & $\begin{array}{c}\text { Perubahan } \\
\text { Tahun 2003- } \\
2018 \\
\end{array}$ & $\begin{array}{l}\text { Persentase } \\
\text { Perubahan }\end{array}$ & Keterangan & Standar & Kategori \\
\hline $\begin{array}{l}\text { Perkembangan } \\
\text { kedekatan lokasi } \\
\text { industri }\end{array}$ & 0,06 & $33,33 \%$ & $\begin{array}{l}\text { Berkembang dengan } \\
\mathrm{T}<0,7\end{array}$ & 0,7 & $\begin{array}{l}\text { Sangat } \\
\text { berkembang }\end{array}$ \\
\hline $\begin{array}{l}\text { Pertumbuhan } \\
\text { jumlah industri }\end{array}$ & 24 unit & $133,33 \%$ & $\begin{array}{l}\text { Perkembangan } \\
\text { kurang sesuai } \\
\text { peruntukan ruang }\end{array}$ & - & Berkembang \\
\hline $\begin{array}{l}\text { Perkembangan } \\
\text { tenaga kerja }\end{array}$ & 8.246 jiwa & $133,40 \%$ & 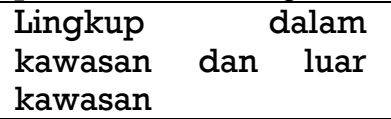 & - & $\begin{array}{l}\text { Sangat } \\
\text { berkembang }\end{array}$ \\
\hline $\begin{array}{l}\text { Perubahan } \\
\text { jaringan jalan }\end{array}$ & $33,78 \mathrm{~km}$ & $56,54 \%$ & $\begin{array}{l}\text { Jaringan jalan dalam } \\
\text { kondisi baik }\end{array}$ & - & $\begin{array}{l}\text { Sangat } \\
\text { berubah }\end{array}$ \\
\hline $\begin{array}{l}\text { Perubahan } \\
\text { pelayanan jalan }\end{array}$ & $0-0,3(<0,75)$ & 2-3 tingkat & $\begin{array}{l}\text { Pelayanan } \quad \text { jaringan } \\
\text { jalan masih }<0,75\end{array}$ & $<0,75$ & Berubah \\
\hline $\begin{array}{l}\text { Perubahan } \\
\text { pelayanan sarana } \\
\text { transportasi } \\
\text { umum }\end{array}$ & \multicolumn{4}{|c|}{$\begin{array}{l}\text { Rute bertambah, kawasan terlayani sarana transportasi umum, } \\
\text { terdapat perbaikan kualitas sarana }\end{array}$} & $\begin{array}{l}\text { Sangat } \\
\text { berubah }\end{array}$ \\
\hline $\begin{array}{l}\text { Perubahan } \\
\text { penggunaan }\end{array}$ & 365,58 ha & $12,60 \%$ & & - & $\begin{array}{l}\text { Sangat } \\
\text { berubah }\end{array}$ \\
\hline
\end{tabular}


Darul Amal Sholihah dkk, Dampak Perkembangan Aglomerasi Industri...

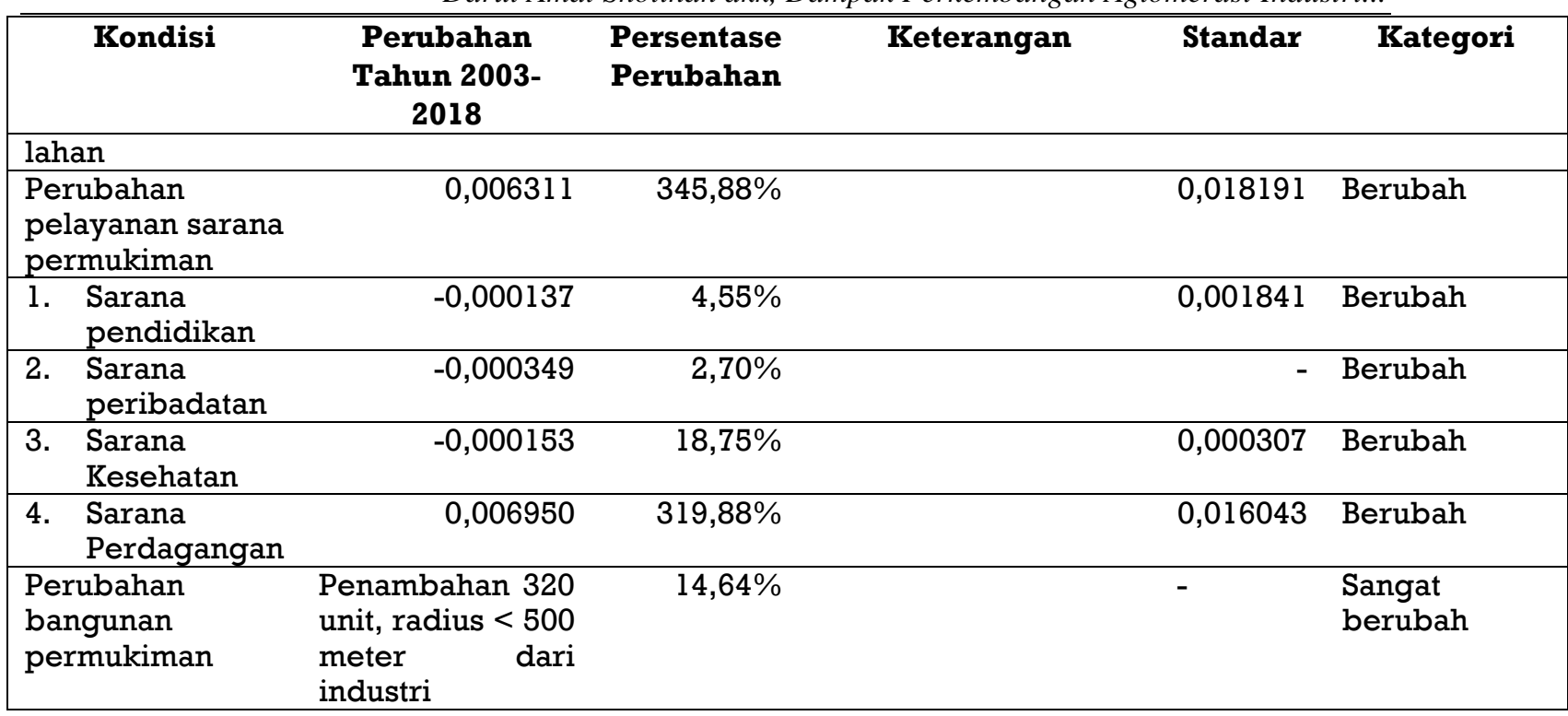

Sumber: Peneliti, 2018

Berdasarkan tabel perkembangan aglomerasi industri Gondangrejo dan perubahan spasial di atas, maka dilakukan analisis matriks keterkaitan antar subvariabel dan skoring hubungan antara masing-masing sub-variabel perkembangan aglomerasi industri Gondangrejo dengan sub-variabel perubahan spasial.

Tabel 5. Hasil Matriks Keterkaitan Antar Sub-Variabel Penelitian

\begin{tabular}{|c|c|c|}
\hline $\begin{array}{c}\text { Keterkaitan/ } \\
\text { Hubungan }\end{array}$ & $\begin{array}{c}\text { Sub-variabel Perkembangan } \\
\text { Aglomerasi Industri }\end{array}$ & Sub-variabel Perubahan Spasial \\
\hline Tidak Berhubungan & - & - \\
\hline \multirow[t]{2}{*}{ Berhubungan } & $\begin{array}{l}\text { perkembangan kedekatan lokasi } \\
\text { industri }\end{array}$ & $\begin{array}{l}\text { - perubahan pelayanan jalan } \\
\text { - perubahan pelayanan sarana } \\
\text { permukiman }\end{array}$ \\
\hline & $\begin{array}{l}\text { perkembangan jumlah tenaga } \\
\text { kerja }\end{array}$ & $\begin{array}{l}\text { - perubahan pelayanan jalan } \\
\text { - perubahan pelayanan sarana } \\
\text { permukiman }\end{array}$ \\
\hline \multirow[t]{3}{*}{ Hubungan Kuat } & $\begin{array}{l}\text { perkembangan kedekatan lokasi } \\
\text { industri }\end{array}$ & - perubahan jaringan jalan \\
\hline & pertumbuhan jumlah industri & $\begin{array}{l}\text { - } \text { perubahan jaringan jalan } \\
\text { - perubahan pelayanan jalan } \\
\text { - perubahan distribusi dan luas } \\
\text { penggunaan lahan } \\
\text { - perubahan pelayanan sarana } \\
\text { permukiman } \\
\text { - perubahan bangunan } \\
\text { permukiman }\end{array}$ \\
\hline & $\begin{array}{l}\text { perkembangan jumlah tenaga } \\
\text { kerja }\end{array}$ & $\begin{array}{l}\text { - perubahan jaringan jalan } \\
\text { - perubahan pelayanan sarana } \\
\text { transportasi umum } \\
\text { - perubahan distribusi dan luas } \\
\text { penggunaan lahan } \\
\text { - perubahan bangunan } \\
\text { permukiman }\end{array}$ \\
\hline
\end{tabular}

Berdasarkan hasil matriks keterkaitan antar sub-variabel perkembangan aglomerasi industri dan perubahan spasial di atas, maka dapat diketahui besaran skoring dari matriks keterkaitan antar sub-variabel sebagai berikut: 
Tabel 6. Hasil Skoring Matriks Hubungan Tiap Sub-Variabel Penelitian

\begin{tabular}{|c|c|c|c|c|c|c|c|}
\hline & & & & & & & \\
\hline $\begin{array}{l}\text { Perkembangan } \\
\text { Aglomerasi } \\
\text { Industri }\end{array}$ & 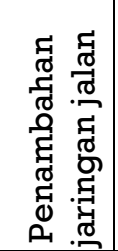 & 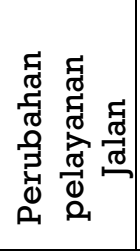 & 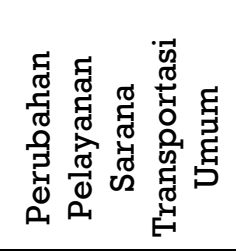 & 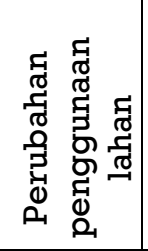 & 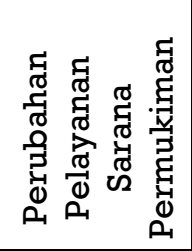 & 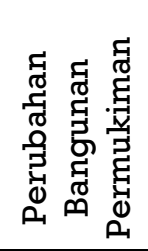 & 䑐 \\
\hline $\begin{array}{ll}\begin{array}{l}\text { Perkembangan } \\
\text { kedekatan } \\
\text { industri }\end{array} & \text { lokasi } \\
\end{array}$ & 2 & l & - & \begin{tabular}{l|l}
- &
\end{tabular} & 1 & - & 4 \\
\hline $\begin{array}{l}\text { Pertumbuhan jumlah } \\
\text { industri }\end{array}$ & 2 & 2 & - & 2 & 2 & 2 & 10 \\
\hline $\begin{array}{l}\text { Perkembangan jumlah } \\
\text { tenaga kerja }\end{array}$ & 2 & 1 & 2 & 2 & 1 & 2 & 10 \\
\hline & & Juml & ah Total & & & & 24 \\
\hline
\end{tabular}

Sumber: Peneliti, 2018

Berdasarkan hasil skoring didapatkan bahwa skor hubungan antara perkembangan aglomerasi industri dengan perubahan spasial mendapatkan skor 24 (Lihat Tabel 6.). Berdasarkan teknik analisis yang telah disusun, skor ini $>20$ (Lihat Tabel 3.). Sehingga, dapat disimpulkan bahwa perkembangan aglomerasi industri Gondangrejo sangat berdampak terhadap perubahan spasial kawasan sekitar.

Dampak dari perkembangan aglomerasi industri teridentifikasi menjadi dampak positif dan dampak negatif. Adapun dampak positif yang ditimbulkan adalah terjadinya penambahan jaringan jalan di kawasan penelitian yang semakin meningkatkan dan memudahkan aksesibilitas, peningkatan pelayanan sarana transportasi umum yang mendukung kemudahan mobilitas tenaga kerja tanpa menggunakan kendaranaan motor pribadi, serta peningkatan pelayanan sarana permukiman yang tercermin melalui peningkatan jumlah sarana permukiman. Sementara, dampak negatif terlihat dari penurunan tingkat pelayanan jaringan jalan yang cenderung mengarah pada taraf jenuh, perubahan penggunaan lahan yang ditunjukkan dengan semakin berkurangnya lahan tidak terbangun atau lahan terbuka, serta peningkatan bangunan permukiman yang semakin menambah kepadatan bangunan di kawasan penelitian.

Selain dampak positif dan dampak negatif dari masing-masing sub-variabel penelitian, dampak terbesar yang ditimbulkan dari perkembangan aglomerasi industri adalah terkonsentrasinya aktivitas pada lokasi-lokasi tertentu (Lihat Peta 6. dan Peta 7.). Konsentrasi tidak hanya dikarenakan adanya aglomerasi industri, tetapi juga berakibat terhadap konsentrasi sarana prasarana dan permukiman pada suatu kawasan tertentu. Hal ini memicu terciptanya pusat-pusat pertumbuhan baru di kawasan penelitian yang berdampak terhadap struktur ruang kawasan.

Perkembangan aglomerasi industri Gondangrejo berakibat pada perubahan morfologi kota yang menimbulkan perbedaan jelas antara kawasan mengalami pertumbuhan dengan kawasan yang tidak mengalami pertumbuhan. Kawasan yang 
Darul Amal Sholihah dkk, Dampak Perkembangan Aglomerasi Industri... mengalami pertumbuhan ditandai dengan dominasi industri, sarana perdagangan jasa, dan perumahan para pekerja. Sementara kawasan yang tidak mengalami pertumbuhan ditandai dengan dominasi permukiman pedesaan. Kedua kawasan yang memiliki perbedaan karakter ruang ini dihubungkan dengan kawasan hijau yang berupa area persawahan (Lihat Peta 6. dan Peta 7.).

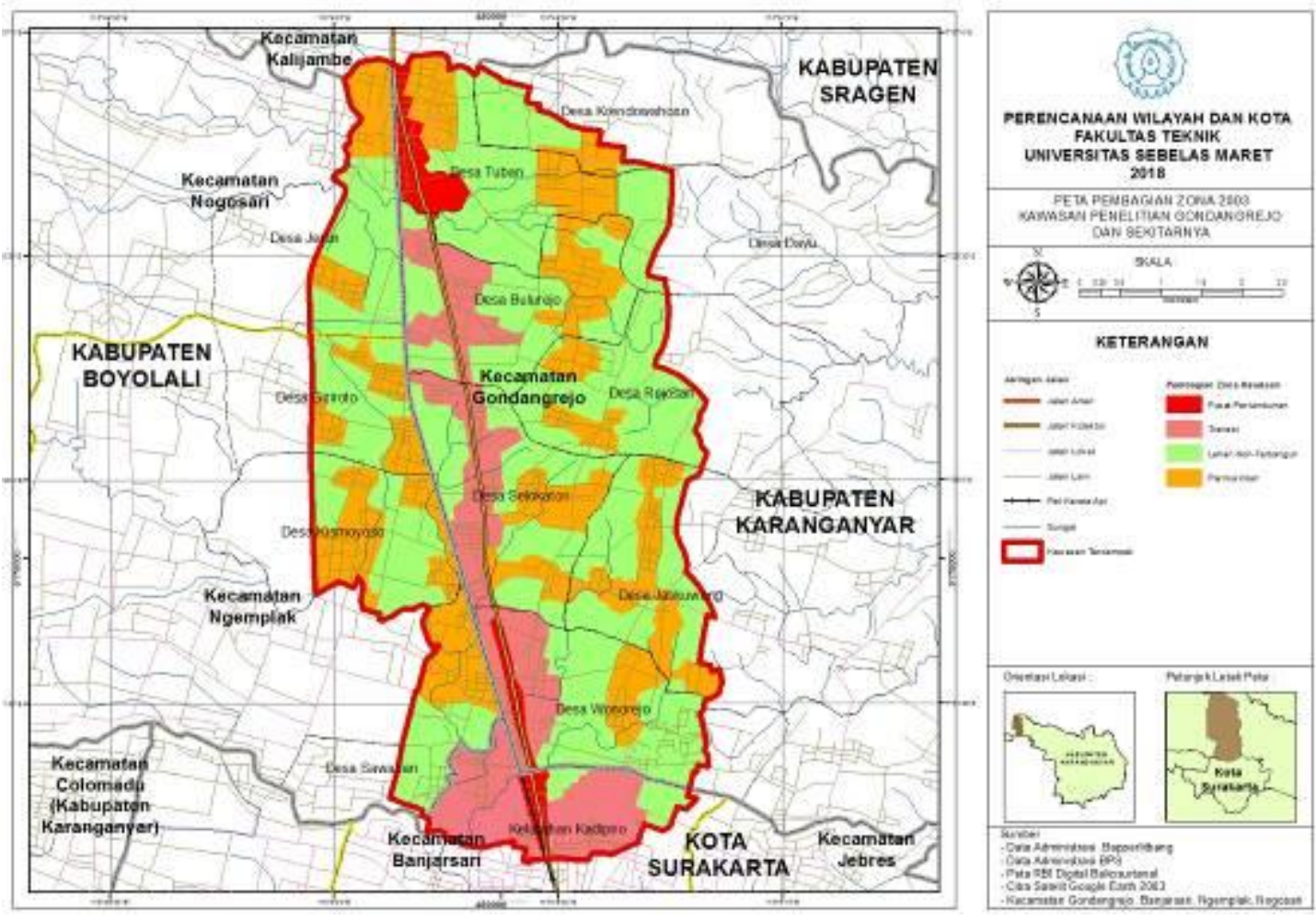

Gambar 6. Peta Pembagian Zona Kawasan Penelitian Tahun 2003

Sumber: Analisis Penulis, 2018 


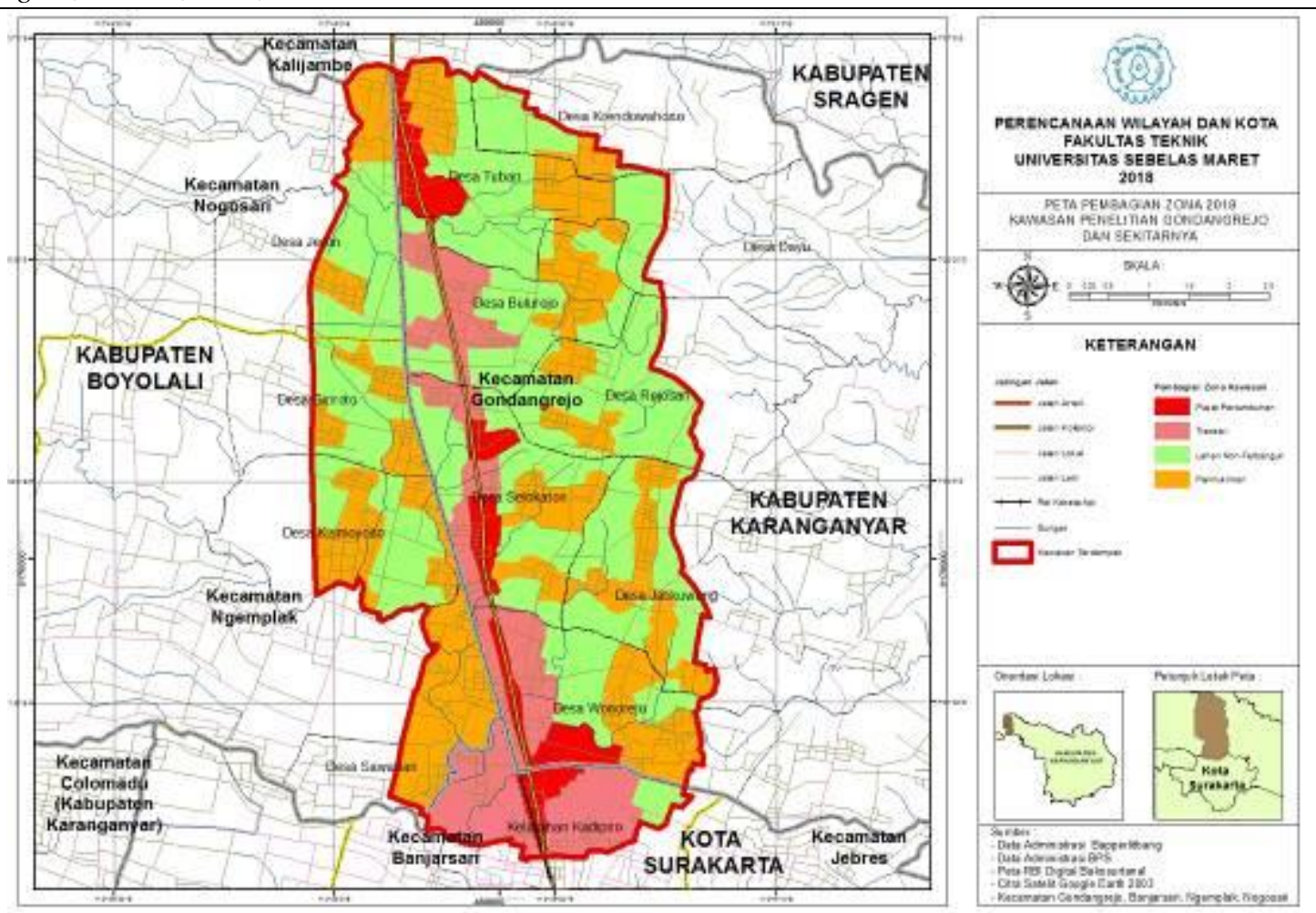

Gambar 7. Peta Pembagian Zona Kawasan Penelitian Tahun 2018

Sumber: Analisis Penulis, 2018

Berdasarkan peta di atas, dapat diketahui bahwa perkembangan aglomerasi industri Gondangrejo berdampak dalam membentuk struktur ruang wilayah kaitannya terhadap pusat-pusat pertumbuhan wilayah. Selama kurun waktu tahun 2003 hingga tahun 2018, perkembangan aglomerasi industri berdampak terhadap perkembangan sarana prasarana yang berakibat terhadap tumbuhnya pusat-pusat kegiatan ekonomi baru di kawasan penelitian. Antara pusat-pusat pertumbuhan juga berpengaruh terhadap perkembangan zona-zona di kawasan penelitian.

Zona-zona yang terbentuk di dalam kawasan penelitian terbagi ke dalam zona utama yaitu pusat pertumbuhan kawasan yang dan zona penunjang yang terdiri dari kawasan permukiman. Antara zona utama dan zona penunjang terdapat border yang membatasi yaitu zona transisi dan lahan non-terbangun, sehingga terlihat jelas perbedaan antara zona utama dengan zona penunjang. Selain itu, kawasan penelitian didominasi dengan permukiman pedesaan, sehingga perkembangan aglomerasi di kawasan penelitian menunjukkan perbedaan yang jelas antara zona utama dan zona zona penunjang melalui pola persebaran penggunaan lahan. Zona utama yang terdiri dari industri dan perdagangan jasa memiliki pola linier, sementara zona penunjang yang terdiri dari permukiman cenderung mengelompok-mengelompok berdasarkan batas administratif dengan dibatasi lahan non-terbangun atau sawah. 
Darul Amal Sholihah dkk, Dampak Perkembangan Aglomerasi Industri... Perubahan yang terjadi selama kurun waktu tahun 2003 hingga tahun 2018 ini semakin menunjukkan perbedaan antara zona-zona di dalam kawasan penelitian. Meskipun, perubahan yang terjadi tidak mencapai taraf berbahaya mengingat masih sesuai dengan kebijakan peruntukan ruang. Akan tetapi, pengembangan perlu dikontrol agar pertumbuhan di bagian pusat kawasan penelitian tidak berdampak buruk terhadap zona-zona yang lain khusunya tidak merusak kawasan lindung sempadan rel dan kawasan lindung cagar budaya yang ada.

\section{KESIMPULAN}

Perkembangan aglomerasi industri Gondangrejo teridentifikasi mengalami perkembangan, dilihat dari perkembangan kedekatan lokasi industri, pertumbuhan jumlah industri, dan peningkatan jumlah tenaga kerja. Identifikasi kedekatan lokasi industri menunjukkan bahwa industri Gondangrejo selalu mengelompok selama tahun 2003 hingga tahun 2018 dan dapat diklasifikasikan ke dalam peristiwa aglomerasi. Perkembangan aglomerasi industri Gondangrejo didukung oleh beberapa faktor, diantaranya faktor kebijakan lokasi peruntukan industri, kemudahan aksesibilitas, dukungan sarana prasarana wilayah, akumulasi tenaga kerja, serta kedekatan lokasi pasar. Pertumbuhan jumlah industri selama kurun waktu tahun 2003 hingga tahun 2018 mencapai 24 unit atau sebesar 133,33\%, yang berbanding lurus dengan peningkatan jumlah tenaga kerja mencapai 8.246 jiwa atau $133,40 \%$.

Kondisi spasial pada kawasan aglomerasi industri mengalami perubahan berupa penambahan jaringan jalan sebesar $33,78 \mathrm{~km}$ atau 56,54\%; penurunan tingkat pelayanan jalan sebesar 2-3 tingkat; peningkatan sarana transportasi umum, perubahan penggunaan lahan sebesar 721,07 ha atau 24,86\% (khususnya peningkatan lahan industri, permukiman, dan perdagangan jasa, serta penurunan lahan sawah/tegal); peningkatan sarana permukiman mencapai 345,88\% yang terdiri dari peningkatan sarana pendidikan, peribadatan, kesehatan, dan perdagangan jasa; serta peningkatan bangunan permukiman dalam radius $<500$ meter dari lokasi industri.

Perkembangan aglomerasi industri Gondangrejo berhubungan kuat dengan penambahan jaringan jalan, peningkatan sarana transportasi umum, perubahan penggunaan lahan, serta peningkatan bangunan permukiman. Perkembangan aglomerasi industri Gondangrejo memicu perubahan keruangan kawasan terdampak perkembangan aglomerasi industri Gondangrejo yang berdampak terhadap perkembangan sektor ekonomi yang ditandai dengan pertumbuhan pusat-pusat baru dengan dominasi lahan industri, perdagangan jasa, dan 
Region, Vol. 13, No.2, Juli 2018: 115-132

permukiman perumahan guna mendukung penyelenggaraan industri.

Pertumbuhan pusat-pusat baru ini semakin memperlihatkan perbedaan antara zona pusat pertumbuhan, zona tidak terbangun, dan zona permukiman pedesaan. Perkembangan pada kawasan aglomerasi industri telah meluas ke arah kawasan lindung cagar budaya, sehingga perlu adanya upaya pengendalian untuk mencegah kerusakan kawasan lindung.

\section{UCAPAN TERIMA KASIH}

Penelitian ini didukung oleh beberapa pihak. Penulis mengucapkan terima kasih atas bimbingan, dukungan, dan partisipasi dari semua pihak yang telah terlibat dalam penelitian ini. Terima kasih atas saran dan masukan yang membangun untuk menjadikan penelitian ini lebih baik.

\section{REFERENCES}

Abdullah. (2010). Pengaruh Perkembangan Industri terhadap Pola Pemanfaatan Lahan di Wilayah Kecamatan Bergas Kabupaten Semarang. Graduate. Theses. Semarang: Universitas Diponegoro.

Arsyad, Lincolin, dan Stephanus, Eri, K.. (2014). Ekonomika Industri Pendekatan Struktur, Perilaku, dan Kinerja. Yogyakarta: UPP STIM YKPN.

BPS. (2017). Karanganyar dalam Angka 2016. Karanganyar: Badan Pusat Statistik

BPS. (2017). Gondangrejo dalam Angka 2016. Karanganyar: Badan Pusat Statistik

Desita, et al. (2017). Klasifikasi Karateristik Dampak Industri pada Kawasan Permukiman Terdampak Industri di Cemani Kabupaten Sukoharjo. Jurnal Arsitektura. No. 1 Vol. 15. April 2017.

Ginting, Perdana. (2007). Sistem Pengelolaan Lingkungan dan Limbah Industri, Cetakan Pertama. Bandung: Yrama Widya.

Kamus Besar Bahasa Indonesia (KBBI) Online, 2018

KM. (2006). Manajemen dan Rekayasa Lalu Lintas di Jalan. Nomor 14.

Kuncoro, Mudrajat. (2002). Analisis Spasial dan Regional, Studi Aglomerasi dan Kluster Industri Indonesia. Yogyakarta: UPP AMP YKPN.

Peraturan Menteri Perindustrian Nomor 35 tahun 2010 tentang Pedoman Teknis Pengembangan Kawasan Industri

Prihanto, Teguh. (2010). Perubahan Spasial dan Sosial Budaya sebagai Dampak Megaurban di Daerah Pinggiran Kota Semarang. Jurnal Teknik Sipil dan Perencanaan UNNES. No. 1 Vol. 12 : 131-140 Januari 2010.

Sabari, Yunus, Hadi. (2005). Manajemen Kota Perspektif Spasial. Yogyakarta: Pustaka Pelajar.

Sabari, Yunus, Hadi. (2002). Struktur Tata Ruang Kota. Yogyakarta: Pustaka Pelajar.

Suchaini, Udin. (2013). Industrial District Fenomea Aglomerasi dan Karakteristik Lokasi Industri. Jakarta: Dapur Buku.

Tambunan, Mangapul P. (2002). Pola Persebaran Industri di Koridor Jalan Raya Bogor. Jurnal, Makara, Sains. No. 3 Vol. 6. Desember 2002.

Tarigan, Robinson. (2012). Perencanaan Pembangunan Wilayah (Edisi Revisi). Jakarta: Bumi Aksara.

Tilaar, Sonny. (2010). Tinjauan Sebaran Lokasi Aglomerasi Industri di Indonesia. Jurnal Tekno. No. 52. Vol. 7. April 2010.

Undang-Undang Nomor 3 Tahun 2014 tentang Perindustrian 